\title{
The Applicability of Soil's Fertilizers in Increasing of Production Effects in Lolium Perenne and Lolium Multiflorum Cultivation
}

\author{
Sosnowski Jacek and Jankowski Kazimierz \\ Siedlce University of Natural Sciences and Humanities, Faculty of Natural Science, Institute of Agronomy Siedlce 08-110, Poland
}

Received: February 3, 2014 / Accepted: March 19, 2015 / Published: March 31, 2015.

\begin{abstract}
The aim of the study was to determine the effect of soil fertilizers, used on the background of NPK fertilization on the productivity of Lolium perenne and Lolium multiflorum in different time of harvest. In 2012-2013 the following species and varieties of forage grasses: Lolium perenne and Lolium multiflorum were cultivated. It was the fallowing experimental subjects: K-control (without fertilization and fertilizer), NPK (N-150 kg ha ${ }^{-1}$ as a $34 \%$ ammonium nitrate, $\mathrm{P}-80 \mathrm{~kg} \mathrm{P}_{2} \mathrm{O}_{5} \mathrm{ha}^{-1}, \mathrm{~K}^{-120 ~} \mathrm{~kg} \mathrm{~K}_{2} \mathrm{O}$ ha ${ }^{-1}$ ), UG-UGmax bio-preparation, EU-Eco bio-preparation (fertilizer), HA-Humus Active as bio-preparation.
\end{abstract}

Key words: Bio-preparations, soil's medium amendment, yield, grass.

\section{Introduction}

Preparations as soil conditioners due to humus and microorganisms contribute to the improvement of the biological activity of soil, increasing the binding of free nitrogen from the air, reducing the erosion and loss of nutrients. Fertilizer is also seen as a preparation useful in crop protection, especially in pro-ecological crops. The aim of the study was to determine the effect of three soil fertilizers, used on the background of NPK fertilization on the productivity of Lolium perenne and Lolium multiflorum in different time of harvest.

\section{Materials and Methods}

On the experimental objects of Grassland Department in 2012-2013 the following species and varieties of forage grasses: Lolium perenne and Lolium multiflorum were cultivated. The fallowing experimental treatments were used:

K-control (without fertilization and fertilizer);

Corresponding author: Sosnowski Jacek, Ph.D., research field: grassland science. E-mail: laki@uph.edu.pl.
NPK-N-150 $\mathrm{kg} \cdot \mathrm{ha}^{-1}$ as $34 \%$ ammonium nitrate was used in three divided doses, sown under each re-growth. Phosphorus fertilization $\mathrm{P}-80 \mathrm{~kg} \cdot \mathrm{ha}^{-1}$ as $46 \%$ superphosphate was sowed once for spring re-growth, $\mathrm{K}-120 \mathrm{~kg} \mathrm{~K} \cdot \mathrm{ha}^{-1}$ of $60 \%$ potassium, was applied for each regrowth, in three equal doses;

UG-UGmax as biological preparation was used annually for spring re-growth in the shooting phase of the grass, at a dose of $0.9 \mathrm{~L} \cdot \mathrm{ha}^{-1}$;

EU-Eco fertilizer as biological preparation was used annually for spring re-growth in the shooting phase of the grass, at a dose of $5 \mathrm{~L} \cdot \mathrm{ha}^{-1}$;

HA-Humus Active as biological preparation was used annually for spring re-growth in the shooting phase of the grass, at a dose of $50 \mathrm{~L} \cdot \mathrm{ha}^{-1}$.

The composition of biological preparations are shown in Table 1. The formulations in the form of a spray were used. All objects were three times out in 2012-2013. An assessment of the level of dry matter yields of plants $\left(t \cdot h \mathrm{~h}^{-1}\right)$, was done. On this base the yield increase for each object relative to the control fertilizer-K was also calculated. The results were evaluated statistically by performing analysis of 
variance. Differentiation medium was verified by Tukey's test at a significance level of $p \leq 0.05$.

Conditions area of research were typical for IX-eastern district of Polish agro-climatic. Average annual air temperature ranged from 6.7 to $6.9{ }^{\circ} \mathrm{C}$, and in summer the average daily temperature was $15{ }^{\circ} \mathrm{C}$. Annual precipitation were at the level of $550-650 \mathrm{~mm}$ and they were not frequent, but heavy. The growing season mostly started in the first decade of April and ending on the third of October, and thus lasted from 200 to 220 days.

\section{Results and Discussion}

When analyzing the productivity of grass species tested against experimental combinations in different cuts (Table. 2), it was showed that the significantly highest dry matter yield was obtained by cultivation of Lolium perenne $\left(6.88 \mathrm{t} \mathrm{DM} \cdot \mathrm{ha}^{-1}\right)$ on the objects fertilized with mineral fertilizers and fertilizer UGmax in the third cut (P3, NPK $+\mathrm{UG})$. Yields above $6 \mathrm{t}$ per hectare were also obtained from Lolium multiflorum $\left(6.88 \mathrm{t} \mathrm{DM} \cdot \mathrm{ha}^{-1}\right)$ supplied with mineral fertilizer with Humus Aktive preparation in the first cut (P1, NPK + HA) as well as in the first cut of Lolium perenne (6.40 t DM.ha ${ }^{-1}$ ) of the objects without NPK fertilizer but Eco-fertilizer sprayed (P1, EU).

Analysing the yield increase (Figs. 1 and 2) in relation to control (without fertilization object) should be stated that in the case of Lolium perenne, intensive productivity of plant biomass occurred in the plots fertilized with NPK and UGmax. Increment of yield exceeded here $6 \mathrm{t} \mathrm{DM} \cdot \mathrm{ha}^{-1}$. The lowest increase was achieved using only Eco-fertilizer $\left(0.33 \mathrm{t} \mathrm{DM} \cdot \mathrm{ha}^{-1}\right)$. The highest increase of Lolium multiflorum yield $\left(7.54 \mathrm{t} \mathrm{DM} \cdot \mathrm{ha}^{-1}\right)$ reached on objects of NPK fertilizer and Humus Active preparation. Large values of this parameter were obtained using only Humus Active $\left(5.54 \mathrm{t} \mathrm{DM} \cdot \mathrm{ha}^{-1}\right)$ and in the combination of NPK with UGmax $\left(4.24 \mathrm{t} \mathrm{DM} \cdot \mathrm{ha}^{-1}\right)$. The lowest increase of this species was recorded in the plots supplied with Eco-fertilizer $\left(2.53 \mathrm{t} \mathrm{DM} \cdot \mathrm{ha}^{-1}\right)$.

Observed positive effect of microbiological preparations on the growth and physiological condition of the plants, especially after the use of preparation spray according to Klama et al. [1] can be explained by microbial cell secretions. The increase in the yield of crops after application of soil fertilizer UGmax during the cultivation also presented Sulewska et al. [2], Sosnowski and Jankowski [3], Kotwicz et al. [4], Sosnowski [5-7], Zarzecka et al. [8], Kołodziejczyk et al. [9] and Zarzecka and Gugała [10]. In the literature, there are also reports in which there was no effect of soil fertilizer on production traits of crops [11].

Table 1 Composition of biological preparations.

\begin{tabular}{|c|c|c|c|c|c|c|c|c|c|c|}
\hline \multirow{2}{*}{ Preparation } & \multicolumn{6}{|c|}{ Macronutrients $\left(\mathrm{g} \cdot \mathrm{kg}^{-1}\right)$} & \multicolumn{4}{|c|}{$\begin{array}{l}\text { Micronutrients } \\
\left(\mathrm{mg} \cdot \mathrm{kg}^{-1}\right)\end{array}$} \\
\hline & $\mathrm{N}$ & $\mathrm{P}_{2} \mathrm{O}_{5}$ & $\mathrm{~K}_{2} \mathrm{O}$ & $\mathrm{Ca}$ & $\mathrm{Mg}$ & $\mathrm{Na}$ & $\mathrm{Mn}$ & $\mathrm{Fe}$ & $\mathrm{Zn}$ & $\mathrm{Cu}$ \\
\hline \multirow{3}{*}{ UGmax } & 1.2 & 0.5 & 3.5 & - & 0.1 & 0.2 & 0.3 & - & - & - \\
\hline & \multicolumn{10}{|c|}{ Organic components } \\
\hline & \multicolumn{10}{|c|}{$\begin{array}{l}\text { Improve soil preparation containing lactic acid bacteria, photosynthetic bacteria, Azotobacter, Pseudomonas, yeasts } \\
\text { and Actinomycetes and micro-and macroelements. }\end{array}$} \\
\hline \multirow[b]{3}{*}{ Eco fertilizer } & 0.6 & 0.6 & 0.8 & - & - & - & - & - & - & - \\
\hline & \multicolumn{10}{|c|}{ Organic components } \\
\hline & \multicolumn{10}{|c|}{$\begin{array}{l}\text { Item breeding earthworms Eisenia fetida, improving the soil, it is the extract of vermicompost cattle in the form of a } \\
\text { suspension-characterized by the presence and diversity of saprophytic fungi, including mikorytycznych, protect the } \\
\text { root system from getting infected soil pathogens. }\end{array}$} \\
\hline \multirow{3}{*}{$\begin{array}{l}\text { Humus } \\
\text { Active Papka }\end{array}$} & 0.2 & 3.0 & 5.5 & 3.0 & 0.5 & - & 15 & 500 & 3 & 1 \\
\hline & \multicolumn{10}{|c|}{ Organic components } \\
\hline & $\begin{array}{l}\text { Impr } \\
\text { (Azot }\end{array}$ & oil prep & on, it i & $\begin{array}{l}\text { npose } \\
\text { osynth }\end{array}$ & $0 \%$ or & mattc & $\begin{array}{l}\text { e for } \\
\text { e). }\end{array}$ & umu & & organisms \\
\hline
\end{tabular}


The Applicability of Soil Fertilizers in Increasing of Production Effects in Lolium Perenne and Lolium Multiflorum Cultivation

Table 2 Yield (t DM:ha ${ }^{-1}$ ) Lolium perenne and Lolium multiflorum depending on NPK fertilizer and preparation in each cut (average for year).

\begin{tabular}{|c|c|c|c|c|c|c|c|c|c|c|c|c|}
\hline \multirow{3}{*}{ Cut } & \multirow{3}{*}{ Species } & \multicolumn{10}{|c|}{ NPK fertilization } & \multirow{3}{*}{ Mean } \\
\hline & & \multicolumn{4}{|c|}{ Bez without NPK } & \multicolumn{4}{|c|}{ NPK } & \multirow{2}{*}{\multicolumn{2}{|c|}{ - Bez NPK NPK }} & \\
\hline & & $\mathrm{K}_{0}$ & $\mathrm{UG}$ & $\mathrm{EU}$ & HA & $\mathrm{K}_{\mathrm{NPK}}$ & $\mathrm{UG}$ & $\mathrm{EU}$ & HA & & & \\
\hline \multirow{4}{*}{ P1 } & \multirow{2}{*}{$\mathrm{Lp}$} & 5.08 & 4.22 & 6.40 & 5.18 & 4.85 & 5.67 & 4.10 & 4.57 & 5.58 & 4.43 & \multirow{2}{*}{$4.95 \mathrm{~A}$} \\
\hline & & $\mathrm{Aa}$ & $\mathrm{Aa}$ & $\mathrm{Aa}$ & Aa & Aa & $\mathrm{Aa}$ & $\mathrm{Ab}$ & $\mathrm{Bab}$ & Aa & $\mathrm{Ab}$ & \\
\hline & \multirow{2}{*}{$\mathrm{Lm}$} & 2.81 & 3.61 & 5.29 & 5.53 & 4.59 & 5.72 & 4.60 & 6.83 & 4.48 & 4.91 & \multirow{2}{*}{$4.88 \mathrm{~A}$} \\
\hline & & $\mathrm{Bb}$ & $\mathrm{Bb}$ & $\mathrm{Aa}$ & $\mathrm{Aa}$ & $\mathrm{Ab}$ & $\mathrm{Aa}$ & $\mathrm{Ab}$ & $\mathrm{Aa}$ & $\mathrm{Aa}$ & $\mathrm{Aa}$ & \\
\hline \multirow{2}{*}{ Mean } & & 3.95 & 3.92 & 5.85 & 5.30 & 4.72 & 5.70 & 4.35 & 5.70 & \multirow{2}{*}{$5.20 \mathrm{a}$} & \multirow{2}{*}{$4.67 \mathrm{~b}$} & \\
\hline & & $\mathrm{b}$ & $\mathrm{b}$ & $\mathrm{a}$ & $\mathrm{a}$ & $\mathrm{a}$ & $\mathrm{a}$ & $\mathrm{a}$ & $\mathrm{a}$ & & & \\
\hline \multirow{4}{*}{ P2 } & \multirow{2}{*}{$\mathrm{Lp}$} & 1.61 & 2.89 & 1.56 & 2.44 & 3.53 & 3.32 & 3.14 & 2.98 & 2.23 & 3.14 & \multirow{2}{*}{$2.69 \mathrm{~A}$} \\
\hline & & $\mathrm{Ab}$ & $\mathrm{Aa}$ & $\mathrm{Ab}$ & $\mathrm{Aa}$ & $\mathrm{Aa}$ & $\mathrm{Aa}$ & $\mathrm{Aab}$ & $\mathrm{Ab}$ & $\mathrm{Ab}$ & $\mathrm{Aa}$ & \\
\hline & \multirow{2}{*}{$\mathrm{Lm}$} & 1.68 & 1.98 & 1.33 & 2.74 & 3.86 & 2.85 & 1.90 & 3.54 & 2.15 & 2.82 & \multirow{2}{*}{$2.49 \mathrm{~A}$} \\
\hline & & $\mathrm{Ab}$ & $\mathrm{Bab}$ & $\mathrm{Ab}$ & $\mathrm{Aa}$ & Aa & $\mathrm{Aab}$ & $\mathrm{Bb}$ & $\mathrm{Aa}$ & $\mathrm{Ab}$ & $\mathrm{Ba}$ & \\
\hline \multirow{2}{*}{ Mean } & & 1.65 & 2.44 & 1.45 & 2.59 & 3.70 & 3.09 & 2.52 & 3.20 & \multirow{2}{*}{$2.20 \mathrm{~b}$} & \multirow{2}{*}{$2.97 \mathrm{a}$} & \\
\hline & & $\mathrm{b}$ & $\mathrm{a}$ & $\mathrm{b}$ & $\mathrm{a}$ & $\mathrm{a}$ & $\mathrm{a}$ & $\mathrm{b}$ & $\mathrm{a}$ & & & \\
\hline \multirow{4}{*}{ P3 } & & 2.61 & 4.10 & 1.67 & 3.97 & 3.66 & 6.88 & 2.89 & 3.74 & 3.78 & 3.60 & \multirow{2}{*}{$3.69 \mathrm{~A}$} \\
\hline & Lp & $\mathrm{Ab}$ & $\mathrm{Aa}$ & $\mathrm{Ab}$ & $\mathrm{Aab}$ & $\mathrm{Ab}$ & $\mathrm{Aa}$ & $\mathrm{Ab}$ & $\mathrm{Ab}$ & $\mathrm{Aa}$ & $\mathrm{Aa}$ & \\
\hline & \multirow{2}{*}{$\mathrm{Lm}$} & 1.47 & 3.60 & 1.87 & 3.22 & 1.06 & 1.60 & 2.28 & 3.13 & 2.04 & 2.52 & \multirow{2}{*}{$2.28 \mathrm{~B}$} \\
\hline & & $\mathrm{Bb}$ & $\mathrm{Ba}$ & $\mathrm{Ab}$ & $\mathrm{Aa}$ & $\mathrm{Bb}$ & $\mathrm{Bb}$ & $\mathrm{Aab}$ & $\mathrm{Aa}$ & $\mathrm{Ba}$ & $\mathrm{Ba}$ & \\
\hline \multirow{2}{*}{ Mean } & & 2.04 & 3.85 & 1.77 & 3.60 & 2.36 & 4.24 & 2.59 & 5.31 & \multirow{2}{*}{$2.91 \mathrm{a}$} & \multirow{2}{*}{$\begin{array}{l}3.53 \\
b\end{array}$} & \\
\hline & & $\mathrm{b}$ & $\mathrm{a}$ & $\mathrm{b}$ & $\mathrm{a}$ & $\mathrm{b}$ & $\mathrm{a}$ & $\mathrm{b}$ & $\mathrm{a}$ & & & \\
\hline
\end{tabular}

Averages in lines marked with the same lowercase letters are not significantly different.

Average in columns marked with the same capital letters are not significantly different.

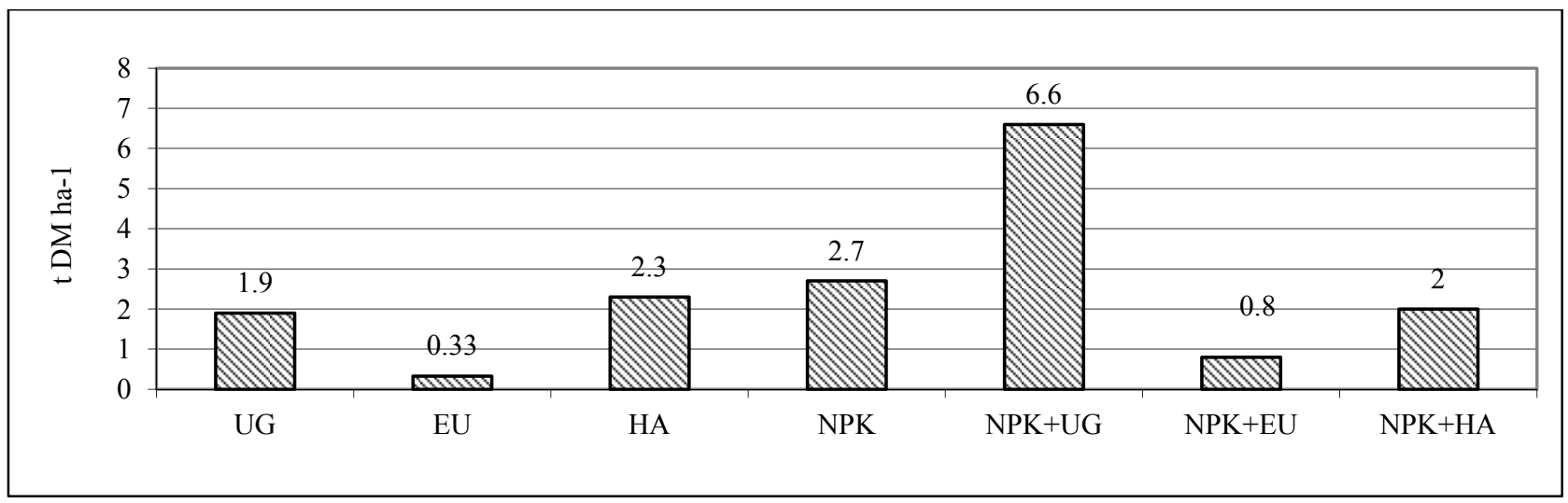

Fig. 1 Increase in yield of Lolium perenne in relation to the control in each experimental objects.

Source: own research.

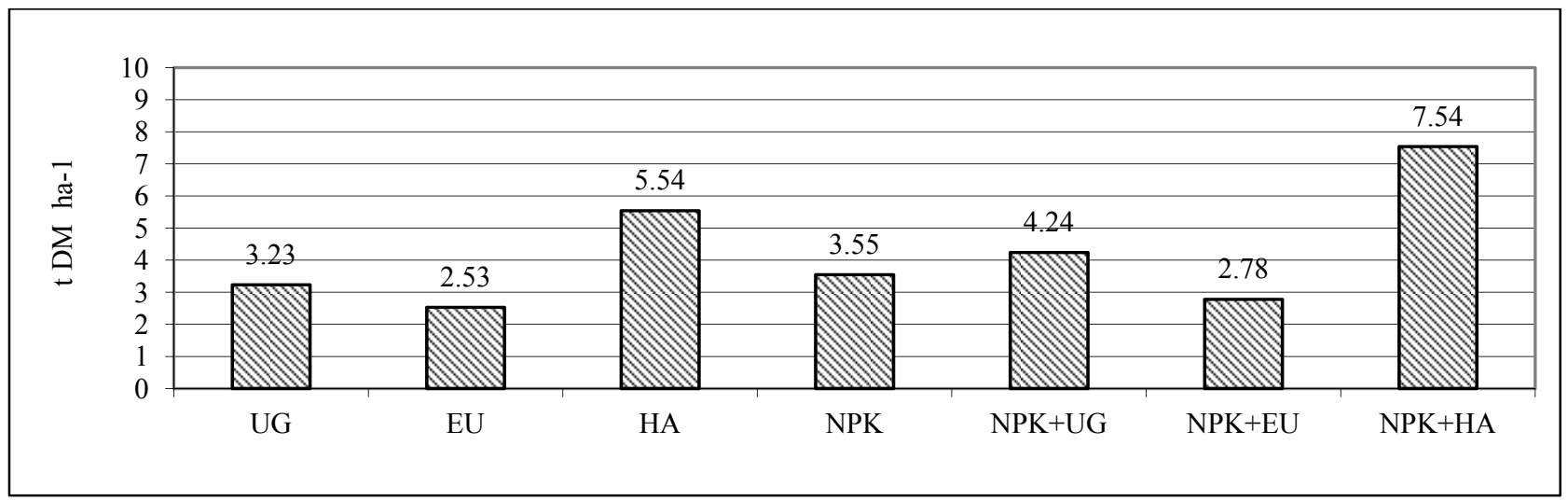

Fig. 2 Increase of Lolium multiflorum yield compared to the control in each experimental objects.

Source: own research. 


\section{Conclusion}

Regardless of the mineral fertilization, the use of soil improvers preparations increased the yield of Lolium perenne and Lolium multiflorum. Regardless of the tested species, on objects without mineral fertilization highest, yields were harvested from plots supplied with UGmax fertilizer and Humus Active. In the case of Lolium perenne best production results were obtained using spray with UGmax preparation. Lolium multiflorum the best yielding actived on objects powered by Active Humus preparation. Analysis of crop regrowth relative to control objects showed that the highest value of this parameter occurred in the cultivation of Lolium perenne on the objects of NPK with UGmax. However, in the case of Lolium multiflorum on the objects of NPK with Humus Active preparation.

\section{References}

[1] Klama, J., Jędryczka, M., Wiśniewska, H., and Gajewski, P. 2010. "Evaluation of Development and Physiological Stage of Winter Wheat and Winter Oilseed Rape Plants Grown with the Application of Effective Microorganisms”. Nauka Przyr. Technol. 4 (6): 1-8.

[2] Sulewska, H., Szymańska, G., and Pecio, A. 2009. "Evaluation of UGmax Soil Additive Applied in Maize Grown for Grain and Silage”. J. Res. Apel. Agric. Eng. 54 (4): $120-5$.

[3] Sosnowski, J., and Jankowski, K. 2010. "Effect of Soil
Fertilizer on the Floristic Composition and Yield of Braun's Festololium Mixtures with Red Clover". Łak. Pol. 13: 157-66.

[4] Kotwica, K., Jaskulska, I., Jaskulski, D., Gałęzewski, L., and Walczak, D. 2011. "Effect of Nitrogen Fertilization and the Method of Soil Fertilization on Winter Wheat Yielding Depending on the Previous Crop". Fragm. Agron. 28 (3): 53-62.

[5] Sosnowski, J. 2011. "Effect of Soil's Fertilizer on the Development of Aboveground bio mass of Festulolium braunii”. Łak. Pol. 14: 115-25.

[6] Sosnowski, J. 2012a. "Development of the above Ground Biomass of Lolium multiflorum Lam. under the Influence of Soil'S Medium Amendment." Ann. UMCS, Sec. E, Agricultura 67: 24-32.

[7] Sosnowski, J. 2012b. "Reaction of Dactylis glomerata L., Festuca pratensis Huds. and Lolium perenne L. to Microbiological Fertilizer and Mineral Fertilization". Acta Sci. Pol. s. Agriculture 11 (1): 91-8.

[8] Zarzecka, K., Gugała, M., and Milewska, A. 2011. "Influence of the Soil Conditioner UGmax on Nitrogen, Phosphorus and Magnesium Contents in Potato Tubers". Prog. Plant Prot/Post. Ochr. Roślin 51 (1): 153-7.

[9] Kołodziejczyk, M., Szmigiel, A., and Kulig, B. 2012. "Yielding of Spring Wheat under Conditions of Differentiated Nitrogen Fertilization and Application of Microbiological Preparations to Improve Soil Properties". Fragm. Agron. 29 (1): 60-9.

[10] Zarzecka, K., and Gugała, M. 2012. "Crop-Yielding Effect of Soil Fertilizer ugmax in Cultivation of Potato". 28: 144-8.

[11] Martyniuk, S., and Księżak, J., 2011. "Evaluation of Pseudo-Microbial Biopreparations Used in Crop Production". Polish Journal of Agronomy 6: 27-33.. 